\title{
Ambiguidade das imagens religiosas no catolicismo à luz da teologia de Paul Tillich: o exemplo de "Nossa Senhora Aparecida" no Brasil"
}

\author{
Etienne Alfred Higuet ${ }^{* *}$
}

\section{RESUMO}

As ambiguidades das imagens religiosas e da devoção aos santos no catolicismo já se manifestam na história da imagem e da devoção a Nossa Senhora Aparecida. Serão destacadas as ambiguidades da fé popular e da religião institucional, em particular os conflitos de interpretação entre as autoridades doutrinais e os fiéis, assim como a mistura de preocupações religiosas com interesses econômicos e políticos. Em seguida, será feita uma leitura dessas ambiguidades à luz da análise tillichiana das ambiguidades da religião: sagrado e profano, divino e demônico.

Palavras-chave: ambiguidade, vida, religião, devoção, santos, conflitos de interpretação.

\section{AMBIGUITY OF RELIGIOUS IMAGES IN CATHOLICISM IN LIGHT OF THE THEOLOGY OF PAUL TILLICH: THE EXAMPLE OF "OUR LADY OF APARECIDA" IN BRAZIL.}

\begin{abstract}
Ambiguities in religious images and devotion to saints in Catholicism are already manifest in the history of the image and devotion to Our Lady of Aparecida in Brazil. The author stresses the ambiguities of popular faith and of institutional religion, particularly conflicts of interpretation between doctrinal authorities and the faithful, as well as the mixture of religious concerns with economical and political interests. The essay
\end{abstract}

* Este texto é a versão ampliada de uma conferência apresentada no XXI Colóquio internacional da Associação Paul Tillich de expressão francesa em Sherbrooke, Canada, 2015. Ver: HIGUET, 2017, p. 275-290.

** Doutor em Ciências teológicas e religiosas; Professor visitante na Universidade Federal de Juiz de Fora, MG, no Programa de Pós-Graduação em Ciências da Religião. 
then reads these ambiguities in the light of a Tillichian analysis of the ambiguities of religion: sacred and profane, divine and demonic.

Keywords: ambiguity, life, religion, devotion, Saints, conflicts of interpretation.

\section{Introdução}

Paul Tillich trata das ambiguidades da vida na quarta parte da sua Teologia Sistemática. Conforme Tillich, "em todo processo vital, estruturas da criação estão misturadas com poderes da destruição de tal forma que não podem ser inequivocamente separados" (TILICH, 2005 , p. 512). Os seres humanos e suas realizações estão expostos às ambiguidades da vida por uma espécie de necessidade trágica, que não depende da boa ou má vontade dos atores, nem das suas deformações de caráter. Isso vale para as principais funções vitais: a auto-integração, que depende da polaridade de individualização e participação; a autocriação, que depende da polaridade de dinâmica e forma; e a autotranscendência, que depende da polaridade de liberdade e destino. A ambiguidade resulta do fato de que as tensões polares que caracterizam o ser na sua essência se transformam em ruptura sob as condições da existência. Em razão da alienação existencial, todos os processos vitais são marcados pela ambiguidade, na qual elementos positivos e negativos estão sempre misturados. As ambiguidades da religião remetem, sobretudo, à função de autotranscendência. São as mais radicais entre as ambiguidades da vida.

Entre as ambiguidades da religião, elegemos as ambiguidades da devoção aos santos, em particular à Virgem Maria, e das suas imagens no catolicismo. Numa primeira parte, desenvolvemos o exemplo da imagem e da devoção a Nossa Senhora Aparecida, padroeira nacional do Brasil. Trata-se de uma imagem de Nossa Senhora da Conceição. Já no século XVI, a doutrina da Imaculada Conceição tinha sido difundida em toda a península ibérica, com o apoio do magistério da Igreja, e especialmente dos Reis Católicos. Nossa Senhora da Conceição era a santa padroeira de Portugal desde que o país tinha reconquistado a sua independência após sessenta anos de dominação espanhola, em 1640, o que foi considerado como um milagre da Virgem. Por esse motivo, ela se tornou logo muito popular no Brasil, após ter sido trazida pelos 
missionários jesuítas. A devoção à Virgem fazia parte da catequese dos missionários e a oração do rosário tornou-se uma constante entre os índios, os negros e o povo todo.

Procuramos primeiro detectar as ambiguidades da devoção a partir de uma análise histórica: ambiguidades do culto autêntico e da idolatria, do maravilhoso e dos milagres; da fé popular e da religião institucional, em particular os conflitos de interpretação entre autoridades doutrinais e fiéis, assim como a mistura de preocupações religiosas com interesses econômicos e políticos. Numa segunda parte, faremos uma leitura dessas ambiguidades à luz da teologia de Paul Tillich: ambiguidade do sagrado (divino-demônico) e de suas expressões simbólicas (idolatriaprofanização, redução do símbolo ao conceito), ambiguidade da santidade e da devoção aos santos.

\section{O caso de Nossa Senhora Aparecida ${ }^{1}$}

\subsection{A imagem}

A história começa com a viagem do novo governador da capitania de São Paulo, Dom Pedro Miguel de Almeida Portugal e Vasconcelos, de São Paulo, onde acabava de assumir suas funções, até Vila Rica, centro da extração do ouro. Dom Pedro precisava passar pelo povoado de Santo Antônio de Guaratinguetá, situado na beira do rio Paraíba, em vista de recuperar suas bagagens, mandadas sobre dorsos de mulas desde o porto de Santos. Por causa do atraso das bagagens, devido à chuva, o governador ficou na aldeia entre o dia 17 e o dia 30 de outubro de 1717. Para tornar a sua estada mais agradável, o conselho municipal convocou os pescadores da região a fim de lhe trazer peixe. Entre eles estavam João Alves, Domingos Martins Garcia e Felipe Pedrosa. Lançaram suas redes no rio sem sucesso durante a noite toda, até que apareceu o corpo, e depois a cabeça, de uma imagem de Nossa Senhora da Conceição, enegrecida por uma longa presença na lama. As redes foram novamente lançadas, várias vezes, e voltaram cheias de peixes. $\mathrm{O}$ fato, que reproduz o milagre da pesca milagrosa no Evangelho, foi atribuído mais tarde à providência, mas não há certeza

\footnotetext{
As nossas principais fontes são: BRUSTOLONI, 1998; RIBEIRO, 1998; ALVAREZ, 2014.
} 
de que os pescadores tiveram logo esta consciência. Aliás, tudo indica que o banquete oferecido ao governador nunca aconteceu, e que Dom Pedro não teve conhecimento do milagre da pesca. ${ }^{2}$ É verdade que, nas estórias populares, as imagens milagrosas costumam aparecer no fundo de um rio, quando não é debaixo das aivecas de um arado. Não tinha nada de extraordinário em encontrar uma imagem num rio, pois era costume descartar uma estátua quebrada, para evitar a maldição. Conforme uma crença popular, a imagem teria sido quebrada quando foi jogada na cabeça de uma serpente que ameaçava uma jovem. Assim como na leitura cristã do terceiro capítulo de Gênesis, Nossa Senhora esmagou a cabeça do réptil.

Depois de achada, a imagem foi colada novamente com cera e guardada na casa de um dos pescadores. Demorou algum tempo antes da família começar a rezar o rosário todos os sábados à noite perante a imagem, com a presença crescente de viajantes a caminho das minas de ouro. A imagem foi doravante invocada pelo nome de Nossa Senhora da Conceição Aparecida. O primeiro milagre trouxe uma "resposta de esperança da imagem negra ao povo brasileiro sofredor" (RIBEIRO, 1998, p. 20). Numa noite, na hora da oração, as duas velas que iluminavam a sala apagaram-se de repente e reacenderam-se sozinhas, após alguns instantes.

$\mathrm{O}$ culto das origens estava desprovido de rigor religioso e passou, durante longos anos, despercebido da Igreja. É que o catolicismo popular no Brasil era - e ainda é em grande parte - uma religião de leigos, transmitida de pai para filho, em razão da ausência secular de assistência pastoral do clero longe dos grandes centros, salvo de modo esporádico para os batizados, casamentos, confissões e comunhões. Mas a Igreja institucional acabou se interessando por uma devoção em constante progresso. O vigário da paróquia de Guaratinguetá, da qual dependia o povoado de Santo Antônio, foi verificar pessoalmente a autenticidade da devoção e, em seguida, foi decidida a construção de uma capela. Uma história difundida na população conta que, cada vez que o vigário queria levar a imagem até a igreja para guarda-la, ela voltava milagrosamente durante a noite. Essa história é significativa do

2 Segundo o relato escrito em 1751, encontrado nos arquivos do Vaticano por volta de 1945, pelo Jesuíta brasileiro, Padre Serafim Leite. 
conflito latente entre a fé popular e a Igreja oficial. Outro sintoma deste conflito é a proibição de beijar a imagem, oficialmente por motivos de segurança. Os fiéis tinham o costume de dormir na capela e organizar nela procissões clandestinas, sem o conhecimento do vigário, quando eles beijavam a imagem. Aos poucos, a imagem foi subtraída aos fiéis, em vista de evitar abusos "idólatras".

A capela tornou-se logo pequena para acolher os devotos e os numerosos ex-votos deixados pelos peregrinos. Foi então construída uma nova igreja, conforme às Constituições do Arcebispado do Brasil, graças à doação de um terreno sobre o "morro dos coqueiros", onde a imagem tinha sido primeiramente conservada. A inauguração oficial aconteceu no dia 26 de julho de 1745, festa de Santa Ana. A capela, frequentada pelos devotos durante cento e trinta e oito anos, está na origem da cidade de Aparecida. Camponeses das redondezas vieram estabelecer-se no lugar e, ao mesmo tempo, surgiu um comércio de artigos de devoção, como em todos os locais de peregrinação.

Ao lado da capela encontrava-se a sala das promessas ou dos milagres, onde se conservava os objetos: mensagens escritas, imagens, roupas, muletas, partes do corpo em cera, ex-votos que dão testemunho do fervor popular. Esta sala existe ainda, nas duas igrejas que foram sucessivamente construídas. Atualmente, em agradecimento pelas graças conseguidas em resposta às promessas dos devotos, encontramos também fotos, placas de bronze ou de plástico, flores artificiais, maquetes de casas, discos, livros, diplomas, troféus, uniformes etc.

Como já foi dito, a imagem não era preta na origem: feita de barro, era pintada, e deve ter perdido as cores pela ação do lodo do rio, e também por causa da fumaça das velas. Mas a cor atual foi usada pela devoção popular para colocar Aparecida do lado dos pobres e dos oprimidos que, muitas vezes, eram escravos negros, povo maltratado que encontrou na imagem a expressão da sua raça, da sua cor, da sua história. Conta-se o caso de um escravo fugitivo, recapturado e a caminho para ser devolvido ao seu dono. Ele pediu a graça de poder rezar frente à capela e, de repente, suas correntes quebraram sozinhas. Para não contrariar a santa, o escravo foi colocado em liberdade. A devoção conservou esta conotação social. Uma lenda popular conta que uma menina, curada da cegueira, teria exclamado ao ver a imagem: 
"Mas ela é negra!". Ela foi logo punida e voltou a ser cega. A estória, embora baseada num erro teológico, contém uma crítica implícita do preconceito racista.

Uma nova igreja, de fato a ampliação da antiga, foi inaugurada em 1888, ano da abolição da escravatura. Ela foi reconhecida como santuário oficial pelo arcebispo Dom Lino Deodato Rodrigues de Carvalho em 1893 e recebeu do papa Pio X o título de basílica menor em 1908. Na época, já havia milhares de peregrinos. Nos anos trinta do século XX, foi planejada a edificação de uma nova basílica, mas seria conservada aquela que se tornaria a Basílica Velha. A construção só começou efetivamente em 1955. A nova basílica foi parcialmente utilizada a partir de 1959. Em 1958, foi criado o arcebispado de Aparecida. A basílica, consagrada e proclamada basílica menor em 1980, pelo papa João Paulo II, continua em construção até hoje, embora esteja faltando pouca coisa. Pelas suas dimensões, é a segunda basílica no mundo, logo depois da basílica de São Pedro em Roma. As obras acompanham o ritmo das doações dos fiéis. Entrementes se desenvolveu um próspero "Centro de apoio ao romeiro", fora do espaço sagrado. Em 1984, a Conferência Episcopal declara oficialmente a nova basílica santuário nacional. Há romarias gigantescas na época da festa, em outubro, e também em maio. As peregrinações diocesanas dividem os outros domingos do ano. A última grande assembleia do CELAM (Conselho episcopal latino-americano) aconteceu em Aparecida na presença do papa Bento XVI e do cardeal Jorge Bergoglio. Este, agora o papa Francisco, pediu para passar em Aparecida quando visitou o Brasil na ocasião das Jornadas Mundiais da Juventude, embora isso não fizesse parte da programação.

Segundo Rodrigo Alvarez,

É provavelmente essa mistura de fé com paixão e identificação que nos permite entender Aparecida como o primeiro símbolo verdadeiramente nacional, a figura mais antiga de nossa história que representou a unidade do Brasil. [...] Pois até mesmo aqueles que não se sentem próximos a ela, por questões religiosas, sabem que ao ver aquela imagem triangular, com manto azul de veludo e seus bordados em ouro, com o rostinho escuro quase escondido embaixo da coroa desproporcionalmente grande e rica, estão vendo um pedaço do Brasil (ALVAREZ, 2014, p. 20). 
Os romeiros vêm de longe para pedir uma ou outra graça a Nossa Senhora: cura, proteção, sucesso nos estudos, casamento, emprego, melhor situação financeira etc. Outros fizeram uma promessa e vêm "pagar" a graça conseguida, pela própria romaria e pelos objetos deixados na sala das promessas, com uma carta contando o que aconteceu.

Mas isso não agrada todo mundo. Em 1978, a imagem foi objeto de ataque de um jovem evangélico, que a quebrou em mais de duzentos pedaços e muito pó.

Padres disseram na época que Rogério Marcos andava sob a influência narcótica dos sermões de um pastor, aparentemente possuído por uma raiva incontrolável daquilo que desde Calvino e Lutero era o alvo de grande parte da fúria dos protestantes contra os católicos, o culto às imagens e a adoração de figuras humanas, especialmente o culto a Maria (ID., p. 33).

Aliás, Rogério Marcos já tinha agredido uma imagem de santo na paróquia dele, usando para esse fim a toalha do altar. Reconhecido esquizofrênico pelo tribunal, o agressor foi internado num asilo psiquiátrico. A imagem, que já tinha sofrido várias restaurações no decorrer do tempo, especialmente para colar de novo a cabeça, foi restaurada no Museu de Arte de São Paulo. Usando a matéria original na medida do possível - para o devoto, é esta matéria que é "sagrada" - a restauradora precisou remodelar inteiramente algumas partes, inclusive a cabeça. ${ }^{3}$ Outro incidente parecido aconteceu alguns anos mais tarde, quando um pastor da Igreja Universal do Reino de Deus deu um chute a uma imagem de Nossa Senhora Aparecida durante uma emissão de televisão. Ele foi, contudo, desautorizado pela igreja dele e enviado para uma missão longínqua, na África do Sul. Ainda atualmente, os casos de agressão a imagens da Virgem Maria não são raras.

\footnotetext{
3 A jovem restauradora teve que aguentar a supervisão do reitor da Basílica, o padre Isidro. Este queria a todo custo reencontrar a cor original da estátua, assim com devia estar antes da sua estada no fundo do rio. Insatisfeito com a restauração, o padre Izidro chegou a "sequestrar" a imagem para tentar, com a ajuda de dois restauradores amadores, restabelecer a cor primitiva da cabeça. Ele guardou a imagem clandestinamente no próprio quarto durante trinta e quatro dias.
} 


\subsection{Fé, dinheiro e política}

Trazemos a seguir alguns exemplos da ambígua promiscuidade do culto mariano com a economia e a política. Durante os três séculos da colonização portuguesa e ainda durante o Império, a Igreja do Brasil dependia do regime do padroado, que fazia do soberano o verdadeiro chefe da Igreja. Este nomeava os bispos e os párocos e recolhia o dízimo, que redistribuía entre as paróquias. A partir de 1800, o regente Dom João determinou que todo o dinheiro recolhido em Portugal e nas colônias fosse depositado no tesouro real. Para garantir a execução dessa ordem, o governo passou a nomear diretamente os responsáveis pela administração das igrejas e capelas. Em consequência, o caixa de Aparecida foi esvaziado uma primeira vez em 1805 e novamente em 1809, após a chegada da família real ao Brasil. Até o final do regime imperial, os padres de Aparecida só receberam o mínimo necessário para a manutenção da igreja e dos edifícios religiosos. A diocese tornou-se fonte de renda para os amigos do governo imperial, juízes e políticos sem escrúpulos, além dos próprios administradores e do clero. Por esse motivo, a construção da basílica antiga demorou quarenta e três anos.

Após a proclamação da República e a separação da Igreja e do Estado, o santuário foi devolvido à Igreja. No dia 08 de setembro de 1904, cinquenta anos após a definição do dogma da Imaculada Conceição, foi celebrada a cerimônia da coroação de Nossa Senhora Aparecida, na presença de um grande número de bispos e padres. A Igreja queria assim "demonstrar ao regime republicano, que havia banido da Constituição e da vida pública o nome de Deus e da Senhora da Conceição, a força da fé católica e os sentimentos religiosos do povo" (BRUSTOLONI apud ALVAREZ, 2014, p. 181). Os bispos lutavam pelo restabelecimento do ensino religioso nas escolas públicas e a proibição do divórcio, entre outras coisas. O governo de Getúlio Vargas permitiu à Igreja reencontrar parcialmente os privilégios perdidos, obtendo a inclusão na Constituição de 1934 de grande número das suas reivindicações.

Dois momentos fortes foram a inauguração da imensa estátua do Cristo Redentor no Corcovado e a entronização de Nossa Senhora Aparecida como padroeira do Brasil em 1931. Depois de atravessar a cidade do Rio de Janeiro em procissão durante mais de três horas, 
acompanhada por mais de trinta bispos e escoltada pelos almirantes da marinha nacional, a imagem foi recebido pelo chefe do governo provisório, o presidente Getúlio Vargas, na presença do núncio apostólico e das principais autoridades do país. O cardeal Dom Sebastião Leme abraçou então a imagem e a ofereceu ao presidente, que beijou seus pés, embora não fosse religioso. De joelhos, o cardeal proclamou: "Senhora Aparecida, o Brasil é vosso! (ALVAREZ, 2014, p. 192)”. O Brasil inteiro reconhecia assim a sua padroeira como símbolo nacional. $\mathrm{Na}$ inauguração do Cristo Redentor, Dom Leme diria ainda: "ou o Estado reconhece o Deus do povo ou o povo não reconhecerá o Estado" (IBID., p. 193). Era a época da "reconquista" católica na Europa, manifestada pela expansão da Ação Católica e, infelizmente também, do fascismo. A Igreja católica estava pensando, por meio de novas alianças com os Estados, em reconstituir a "cristandade". Era o caso da concordata com Mussolini que, em 1929, estabelecia o Estado do Vaticano e também, mais tarde, da concordata com a Alemanha do Reich.

Para a construção da nova basílica, o presidente Vargas autorizou a doação de dez milhões de cruzeiros do caixa do Estado, reconhecendo a obra como sendo de interesse nacional e concedendo à arquidiocese de Aparecida a isenção de impostos e outros favores legais, como o direito de expropriar terras se necessário. Em 1960, a estrutura metálica da torre principal foi oferecida pelo presidente da república Juscelino Kubitschek de Oliveira. Em troca, a torre levaria o nome de Brasília, como a nova capital inaugurada no mesmo ano.

Pouco antes do golpe de Estado de 1964, foram organizadas por uma parte do clero, alguns movimentos católicos, igrejas protestantes, empresários e certos setores políticos "Marchas da família com Deus pela liberdade". Era uma reação contra o discurso do presidente João Goulart no dia 13 de março, no qual prometia reformas de base, inclusive a reforma agrária. O discurso foi entendido, no contexto da guerra fria, como um passo na direção de uma ditadura comunista. As manifestações reuniram mais de um milhão de pessoas, sobre tudo no Rio e em São Paulo. A vitória do levante que desembocou no golpe de 1964 foi celebrada pela maioria dos bispos e da Igreja católica. Ela foi atribuída a Nossa Senhora Aparecida pelo governador de São Paulo Ademar de Barros e pelo arcebispo do Rio, Dom Jaime Câmara. Os 
padres redentoristas, responsáveis pela administração do santuário de Aparecida, comemoraram também o golpe como "vitória da revolução democrática contra o comunismo" (ALVAREZ, 2014, p. 200), ao agradecer, no jornal da comunidade, a ajuda da santa: "Bendita seja a rainha do Brasil, Nossa Senhora Aparecida!"

O repúdio ao comunismo pelos padres do santuário não era uma novidade: já em 1945, a imagem tinha sido exposta na praça da Sé em São Paulo, porque os padres queriam alertar a população, em particular os operários, contra os grandes riscos do comunismo. Depois do golpe, o novo presidente da república, Marechal Humberto de Alencar Castello Branco convidou a imagem a percorrer o país, com todas as despesas pagas pelo tesouro nacional. A carta, escrita a mão sobre pergaminho, pedia que a padroeira do Brasil fosse levada "em triunfante peregrinação às capitais de todos os Estados do Brasil, sendo em Brasília aclamada geralíssima das gloriosas Forças Armadas Brasileiras”. Para não prejudicar o comércio local, a imagem viajou sucessivamente até cada capital, voltando cada vez a Aparecida. Durante as viagens, era substituída por uma réplica no santuário. Depois disso, visitou mais de mil e trezentas comunidades, nas cinco regiões do Brasil. Foram registradas um milhão e quinhentas mil comunhões. A viagem favoreceu também sobremaneira a coleta de fundos em vista da continuação da construção da nova basílica. Em 1980, por um decreto do general presidente João Figueiredo, a data de 12 de outubro, festa de Nossa Senhora Aparecida, foi declarada feriado nacional. Em 1998, o Centro de Apoio ao Romeiro foi inaugurado pelo presidente da república Fernando Henrique Cardoso.

Em suma, apesar da separação constitucional entre a Igreja e o Estado, o culto mariano sempre recebeu os favores das autoridades políticas, nacionais e regionais. É o caso, por exemplo, de Nossa Senhora de Nazaré em Belém do Pará. Os outros países da América latina foram também consagrados à Virgem Maria, a qual carrega sempre o nome do principal santuário nacional. O fato que os políticos usam a imagem de Maria para servir seus interesses individuais, especialmente eleitorais, não constitui um segredo para ninguém. 


\subsection{A romanização e os redentoristas.}

Pela proclamação da república, em 1889, a Igreja deixa de depender do regime do Padroado, que dava todo poder aos soberanos portugueses e, em seguida, aos imperadores do Brasil, lhes permitindo não aplicar as decisões do Concílio de Trento. Reassumindo a autoridade sobre a igreja na segunda metade do século XIX, os "bispos reformadores" visavam instaurar o catolicismo tridentino, muito mais centrado no clero, na missa e nos sacramentos, na base de uma catequese sistemática e de uma moralização dos comportamentos, do que na devoção individual. Este processo foi chamado de "romanização" pelos historiadores.

Ao contrário, no catolicismo devocional, o acesso do devoto ao santo é pessoal, imediato e exclusivo, por intermédio de uma estátua ou imagem bem definida, e a fé se traduz numa verdadeira intimidade entre o devoto e o santo ou a santa, representados pela imagem. Do lado do fiel, há uma liberdade total de falar com grandes gestos, como se fala a uma pessoa. Diferentemente do que acontece com a relação com Deus - que se tornou distante e abstrato -, cada pessoa escolhe o seu santo de devoção ou, antes, sente-se eleito por ele e estabelece um pacto de aliança, permanente ou temporário. Trata-se sempre de uma troca de favores, sancionada por uma espécie de contrato: promessas para resolver problemas de saúde, de família ou de trabalho (Cfr. HIGUET, 2004, p. 31).

Em Maria, o povo valoriza, sobretudo, a dimensão da maternidade. É o caso também da tradição institucional das Igrejas Cristãs. A mãe é um símbolo abrangente que emite quase sempre energia positiva, afeto, calor, compreensão e vida. A devoção a Maria se vincula às necessidades de base da existência. Para o povo, o importante é salvar sua vida, individual e coletiva, é salvar seu direito de viver com um mínimo de dignidade. Por esse motivo, as argúcias dogmáticas criadas a partir de outro mundo cultural importam pouco (Cfr. GEBARA, BINGEMER, 1987, p. 143). ${ }^{4}$

O processo de romanização se fez sentir também em Aparecida. No momento da proclamação da república em 1889, sobravam poucos padres no Brasil, inclusive em Aparecida, por causa da política

4 Em outro sentido, a teologia feminista mostrou as manipulações do culto mariano operadas no decorrer dos séculos para legitimar concepções determinadas do estatuto da mulher na família e na sociedade. 
imperial de expulsão das grandes ordens religiosas, do fechamento dos seminários e da proibição de formar sacerdotes no território nacional. A solução era importar padres. Os bispos foram à procura, na Europa, de novas congregações pós-tridentinas, sobretudo dedicadas à missão e ao ensino. Os santuários de Aparecida e de Trindade foram entregues à responsabilidade dos redentoristas. Assim, treze religiosos redentoristas alemães chegaram ao Rio de Janeiro em 1894. Aparecida tornou-se centro da província da congregação no Brasil. Os religiosos se encarregaram imediatamente da reorganização da administração do santuário e dos registros de batismo e de casamento. Organizaram o culto, com a missa quotidiana e a administração dos sacramentos. Impressionados pela ignorância da população, deram início à catequese. O seminário redentorista foi fundado em 1898, a casa editorial "Santuário" e o jornal Santuário de Aparecida nasceram em 1900. Eles construíram também um convento, um edifício enorme seguindo o modelo do Palácio de Versalhes. Os padres cuidaram da renovação pastoral da região, por meio de missões populares e pela edição de um Manual do Devoto (Aparecida, 2009). ${ }^{5}$

Em suma, a devoção aos santos, em particular à Virgem Maria, e a veneração das imagens incluem riscos evidentes de idolatria, de magia, de superstição. Pode se dizer o mesmo do maravilhoso e dos milagres relacionados à devoção. Eles provocaram, ao longo da história do cristianismo, reações iconofóbicas e iconoclastas, em particular na Igreja bizantina do século VI e na época da Reforma no Ocidente. Elas determinam, ainda hoje, as relações entre catolicismo e protestantismo, mas também entre religião popular e religião institucional. Na segunda parte, desenvolvemos uma análise a partir da teologia de Paul Tillich, especialmente da sua apresentação das ambiguidades da religião na Teologia Sistemática. I

Seria injusto, sobretudo atualmente, ver nos padres redentoristas simples instrumentos de "romanização". Longe de seguir servilmente as diretrizes dos "bispos reformadores", elaboraram uma catequese integradora, mas profundamente respeitosa das expressões religiosas populares. 


\section{Dialogando com Tillich}

\subsection{As ambiguidades da religião e das imagens}

Para Tillich, todo ato cultural no elemento da linguagem é sempre, ao mesmo tempo, constituição e destruição do sentido. Isso vale também para as criações da linguagem religiosa, inclusive a linguagem das imagens. Na religião, a vida humana se transcende de modo ambíguo, pela ambiguidade do sagrado e do profano e pela ambiguidade do divino e do demônico (Cfr. TILLICH, 1987, p. 102-108). "O sagrado é a qualidade do que preocupa o ser humano de modo último. Conforme Otto, é a presença do divino que transcende a estrutura sujeito-objeto da realidade, o tremendum et fascinosum, o abismo e o fundamento do ser humano (TILLICH, 1968 a , p. 239)". A grandeza da religião é a transparência ao sagrado, isto é, ao fundamento do ser. "Nesse sentido, podemos falar em Escrituras sagradas, comunidades santas, atos sagrados, funções sagradas, pessoas santas (TILLICH, 1968b, p. 105)". No caso das pessoas, sua santidade não é sua qualidade moral, cognitiva ou religiosa, mas o seu poder de remeter além de si mesmas, o seu poder de autotranscendência.

Na religião, a grandeza se torna santidade, mas a religião é também a refutação radical da pretensão da vida à santidade. É que todo ato religioso contém elementos profanizantes. Em particular, pela profanização institucional, a religião se torna, na sua forma institucionalizada, uma parte da realidade finita: prescrições, enunciados doutrinais, grupos de pressão, poder político de força. Tudo isso pode sufocar a experiência religiosa e o fervor da devoção (IBID., p. 106-107).

No caso da ambiguidade do divino e do demônico, o símbolo do demônico não é simplesmente negação do divino, mas participação no poder e na santidade do divino, embora de modo pervertido. O finito (por exemplo, uma nação, uma igreja, uma espiritualidade, uma devoção religiosa ou ainda dimensões parciais de uma personalidade centrada) reivindica a infinidade ou a grandeza divina. O demônico falsifica a transcendência, ao identificar com o sagrado um portador determinado da santidade. ${ }^{6}$ Assim, os santos podem ser veículos da santidade divina,

6 O alemão e o inglês só possuem uma palavra para designar o sagrado e o santo, que podem ser distinguidos nas línguas latinas: heilig, holy. 
mas tornam-se ídolos quando são identificados com o divino. As formas variáveis da existência humana moral e cultural participam do sagrado sem ser, elas mesmas, o sagrado. Quando apresentam a pretensão de ser o sagrado, tornam-se demoníacas.

Isso vale para os grupos portadores do sagrado, como as igrejas, e também para a pessoa do "santo". A comunidade eclesial é santa na medida em que é a manifestação da comunidade espiritual, mas ela é, ao mesmo tempo, a perversão desta comunidade. Do mesmo modo, há indivíduos que antecipam a "vida na presença do Espírito", pelo crescimento da sua consciência, da sua liberdade, da sua solidariedade e da sua autotranscendência. São imagens da perfeição, que se oferecem àqueles que caminham na direção da santificação. A santidade da Igreja e do cristão é a sua transparência ao sagrado. Os princípios de justiça e humanidade são os critérios da autenticidade do sagrado na personalidade santa e na comunidade santa (Cfr. IBID., p. 108-113).

Tillich lembra que o protestantismo não reconhece um tipo de santos possuindo uma superioridade moral em relação aos outros, mas que reconhece a santificação, e que pode sustentar que há seres humanos in-formados pela força do Espírito divino e representando esta força. Isso corresponde a uma forma de religião mais extática do que moral, como a religião popular. Esses seres humanos representam os outros membros da comunidade enquanto símbolos da maturidade no processo de santificação. Eles constituem exemplos da realização do Novo Ser na vida pessoal (Cfr. IBID., p. 252-253). Podemos observar, na piedade mariana brasileira, tanto na experiência religiosa quanto na concepção da santidade subjacente, os traços negativos da demonização e da profanização, assim como a dimensão positiva de representação e transparência ao sagrado.

Nos diálogos que Tillich teve no Japão com interlocutores budistas e missionários cristãos, Tillich trata diretamente da piedade popular. No relato da sua viagem, o nosso teólogo conta que, na ocasião de um encontro com universitários budistas, ele "pôde perguntar sobre o budismo como religião viva e sobre a distorção idolátrica dos símbolos no budismo popular". Ele conclui que, conforme suas próprias impressões, "o budismo enquanto fé popular permanece como problema não resolvido para a maioria deles (TILLICH, 2015, p. 295)". Numa 
discussão com pesquisadores da Universidade Otani, Tillich coloca a mesma pergunta:

Há uma clivagem profunda entre o budismo "no topo" - o dos fundadores, dos sacerdotes, dos monges, dos teólogos, etc. - e o budismo do povo. [...] Haverá no budismo algo análogo [à Reforma protestante]: uma ponte entre a religião popular, sempre suscetível de tornar-se supersticiosa e demonizada, e o "cume" que está além do concreto e mantém uma relação direta com o princípio do Buda ou o princípio último? (IBID., p. 316-317).

No diálogo que se segue, Tillich retoma a sua ideia da demonização, tentando aplica-la ao budismo. Ele se pergunta se os altos responsáveis do budismo fazem algo para que as práticas supersticiosas da religião popular não afastem completamente da religião as classes médias esclarecidas. A resposta budista é que o budismo não é um sistema de doutrina, mas antes de tudo uma experiência. Houve também movimentos de reforma no budismo, como o shin e o zen, que purificaram o budismo, embora imperfeitamente, das formas desviantes mágicas, idólatras ou demônicas, tanto na classe superior intelectual quanto nas classes médias e inferiores. "Desse modo, até os camponeses podiam desfrutar uma experiência religiosa muito profunda (IBID., p. 318)".

Tillich retoma também a concepção do demônico na discussão com os missionários cristãos no Japão. Em seguida, ele lembra a pergunta colocada aos budistas a respeito da piedade popular o observa que a resposta recebida não o satisfez: "Ele estima, de fato, que, de um ponto de vista budista, nada pode ser mecanizado, supersticioso ou demonizado... e ele afirmou que a piedade mais primitiva... pode ser o meio de despertar o espírito do Buda em todo ser humano (IBID., p. 323)". Comparando o budismo e o xintoísmo com a Igreja católica romana, Tillich se pergunta "porque o cristianismo integrou em si tudo isso [entendo que se trata das práticas da piedade popular], porque isso aconteceu a despeito da fundação cristã do cristianismo (IBID., p. 325326)". Ficamos então com a impressão de que Tillich não apreciava positivamente a piedade popular católica, embora não trate aqui do 
tema ex professo. A sua consideração é mais prática e circunstancial do que dogmática.

Do ponto de vista de Tillich, a piedade popular, centrada na experiência, precisa então de uma regulação institucional, para evitar a demonização. Nisso, ele se opõe aos seus interlocutores budistas. Esta regulação foi produzida pela Reforma protestante, que teria criado uma "ponte" entre a piedade popular e a "cúpula". Ela estaria também presente no catolicismo, pelo menos nos mosteiros. Mas, frente a interlocutores budistas, Tillich não se estende sobre a figura que a regulação institucional poderia assumir no cristianismo atual. ${ }^{7}$

\subsection{O que diz Tillich sobre a devoção aos santos e o culto a Maria?}

Tillich vê no culto mariano uma consequência do processo de abstração na consciência religiosa, que afasta a mesma da Trindade e até do Cristo. É que, quando se tornam abstratos, os símbolos não podem mais cumprir sua função de responder a questões essenciais (TILLICH, 1968b, p. 304). O que Tillich diz a respeito do dogma trinitário poderia ser aplicado ao dogma mariano (Imaculada Conceição, Assunção) no catolicismo, que fez do símbolo de Maria uma entidade metafísica. A teologia e o dogma transformam os símbolos em conceitos, o que lhe faz perder seu poder revelador.

Por outro lado, o catolicismo eleva a Virgem Maria a uma posição onde ela quase alcança uma dignidade divina. Para a piedade popular de muitos católicos atuais, Maria possui uma significação bem maior do que o "Espírito Santo" e até do que o Cristo. Se a doutrina da Virgem Maria como corredentora se tornar um dogma (e Tillich prevê que isso irá acontecer), ela será elevada à incondicionalidade e, em consequência, alcançará a posição de uma das pessoas no seio da vida divina (IBID., p. 311). Na realidade, para os católicos, Maria pertence à esfera divina,

De fato, antes de formular sua pergunta, Tillich afirma que a Reforma "aboliu um grande número, senão a maior parte, dos usos próprios da religião popular, em vista de tornar o cristianismo compreensível aos leigos esclarecidos da classe média [surgida no século XVI] (IBID., p. 316).” Aos nossos olhos, em consequência, a Reforma não criou nenhuma verdadeira ponte entre a religião erudita e a religião popular, já que destruiu praticamente esta última. Desse modo, a resposta da Reforma, assim como é formulada por Tillich, não pode nos satisfazer plenamente. Por outro lado, essa "ponte" existe provavelmente nos movimentos de "reavivamento" e pentecostais, seja qual for a maneira como possamos julgar esses movimentos sob outros aspectos. 
não como corredentora, mas como mediadora entre Deus e o ser humano e ela sempre fica subordinada ao mistério divino.

A Virgem Maria não revela mais nada aos protestantes e, para eles, a virgindade de Maria deixou de ser um símbolo do divino. É que a situação na qual este símbolo nasceu deixou de existir: a relação com Deus mudou, a relação direta e imediata com Ele tornou inútil uma instância mediadora. Tillich parece lamentar que, com a luta da Reforma contra todos os mediadores humanos entre Deus e o ser humano, o símbolo da Virgem Maria tenha sido liquidado - e que, por meio desse processo purificador, o elemento feminino na expressão simbólica do que nos preocupa de modo último estivesse, em grande parte, obscurecido (IBID., p. 312). ${ }^{8}$ Todavia, para ele, o simbolismo trinitário pode suprir esta ausência do feminino, ao transcender a alternativa entre o masculino e o feminino (IBID., p. 314). Mas, será mesmo? O princípio protestante não precisaria de um pouco de substância católica? Não deveríamos, de algum modo, "pensar com Tillich para além dele", voltando, se necessário, o pensamento de Tillich contra ele mesmo? ${ }^{9}$

Por exemplo, sabemos que, para Tillich, a procura da vida sem ambiguidade transcende toda forma e todo símbolo religioso nos quais ela se expressa. Nesse sentido, forçando um pouco o pensamento de Tillich, poderíamos ver em Maria um símbolo da vida não ambígua. Ela é símbolo de um novo céu e de uma nova terra e, ao participar da ressurreição do Cristo, ela simboliza a ressurreição do corpo na Assunção: um corpo espiritual é um corpo que exprime a totalidade do ser do ser humano transformado pelo Espírito divino. Ela é também um símbolo cósmico e escatológico. Isso não impede que todas essas imagens e todos esses símbolos tenham que ser transcendidos. Aliás, faz parte da natureza do símbolo religioso o fato de expressar - ou evocar - uma realidade que, pela própria essência, transcende tudo o que pode ser encontrado no mundo da experiência concreta, logo não pode tornar-se objeto de um ato do espírito.

Ao falar na luta contra as ambiguidades na vida das Igrejas e no sentido da Reforma, Tillich se refere à polaridade entre verdade e

Ver também TILLICH, 1978, p. 221.

9 Podemos prolongar a reflexão a partir dos textos de Tillich sobre a "substância católica". Cfr. TILLICH, 1995. 
adaptação. Na Igreja primitiva, as massas assumiram, com o consenso das autoridades eclesiásticas, tendências politeístas, seja pela veneração das imagens ou pelo culto dos santos, especialmente o culto mariano. Sem essas adaptações, a obra missionária teria sido impossível. Mas, no processo de adaptação, o conteúdo da mensagem cristã corre constantemente o perigo de perder-se. Há um risco de abandonar o polo da verdade em nome da adaptação (TILLICH, 1968b, p. 228).

Enfim, não podemos deixar de mencionar a famosa experiência de Tillich com a madona de Botticelli: neste caso, a imagem da Virgem Maria foi reconhecida como digna de deixar transparecer o Incondicionado. No museu de Berlim, Tillich revê a imagem que, na forma de uma reprodução numa revista, o reconfortou durante a batalha de Verdun. Foi uma experiência extática da pura beleza. Algo da fonte divina de todas as coisas o submerge e abala. Este momento afetou a vida toda dele, lhe dando as chaves da interpretação da existência humana e lhe trazendo alegria de viver e verdade espiritual. A imagem abriu a Tillich uma nova dimensão do ser e da própria alma (TILLICH, 1987, p. 234-235).

Não poderíamos estender a todas as imagens o que Tillich diz sobre a pintura? É que, para Tillich, todas as criações artísticas visam para além de si mesmas, elas remetem ao fundamento incondicionado do ser, elas revelam algo do fundamento divino de todas as coisas. Por meio de uma experiência do sagrado, as formas artísticas, tanto religiosas quanto seculares, fornecem as chaves da interpretação da existência humana. Quando contempla uma obra pictural, o ser humano é capaz de romper a superfície das formas e de penetrar, embora de modo fragmentário, no seu teor substancial, no poder espiritual que mora nelas. É o caso de uma religião sacramental, como o catolicismo, onde a Realidade Última é fortemente determinada pelo visual, e associada a objetos, pessoas, símbolos e acontecimentos. A arte transforma os elementos naturais da realidade bruta em símbolos do que transcende o material. Ela tem o poder de antecipar fragmentariamente a salvação, a reconciliação com o infinito (IBID., passim).

Prolonguemos o pensamento de Tillich: o divino se manifesta concretamente em objetos e pessoas. E a relação familiar com o divino inclui a necessidade de ver, ouvir, contemplar, tocar, abraçar, apalpar (Cfr. 
I Jn 1, 1). A fé e a devoção se expressam através do corpo inteiro. Em vez de ver nas figuras, imagens, representações, pessoas e símbolos apenas expressões idólatras e supersticiosas, não poderíamos reconhecer nelas mediações possíveis do Deus supremo? Nenhuma imagem esgota o Seu mistério insondável, mas toda representação evoca um raio da Sua luz.

Tudo isso explica sem dúvida a resistência popular incansável à doutrinação e ao controle da devoção pelo clero. O processo de romanização do catolicismo brasileiro, desde o século XIX até hoje, na louvável intenção de proteger a devoção contra o perigo de demonização, acabou reproduzindo a romanização imperial, que queria unificar a multiplicidade dos povos e das culturas debaixo de um único poder absoluto. Podemos aplicar aqui a análise das ambiguidades da vida na dimensão histórica, na última parte da Teologia Sistemática. A ambiguidade do poder, do império e da centralização corrói todas as sociedades, inclusive as Igrejas. ${ }^{10}$ Tanto a vontade de poder e a consciência de uma missão a cumprir, da parte do colonizador português, e, em seguida, do império brasileiro, senhores da Igreja, quanto a centralização romana produziram uma falsa universalidade que coloniza as consciências e sufoca a criatividade cultural e religiosa, provocando, segundo Tillich, "a perda e a destruição da forma, da vida e do sentido". Ao lutar contra a demonização, caiu-se na profanização, com risco de esvaziar a forma cultual da devoção do seu conteúdo espiritual.

Apesar disso, Nossa Senhora Aparecida entrou na vida dos pobres e dos escravos, como companheira da sua vida cotidiana difícil e inspiradora de numerosas lutas populares. Assim: “As águas do Rio Paraíba enegreceram a imagem, tornaram-na da cor do povo maltratado. Pobres pescadores a recolheram em suas redes e ela renasceu, dando mais força e identidade a eles, sobretudo aos negros da região e circunvizinhanças, que passaram a encontrar nela uma expressão de sua raça, de sua cor, de sua história (GEBARA; BINGEMER, 1987, p. 180-181)". Com isso, não queremos esquecer as ambiguidades da religião popular, como suas tendências individualistas e materialistas e a constante tentação de idolatria, que ameaça toda vida religiosa. Podemos ver isso, por exemplo, no caráter absoluto atribuído pelo devoto ao

10 Cfr. TILLICH, 2005, p. 774-777. 
seu santo e à sua imagem favorita, e na rivalidade consequente entre o santuário nacional de Aparecida e outros santuários no Brasil, os quais competem também entre si.

\section{Conclusão}

Uma das ideias mais interessantes de Tillich diz respeito à mistura indissociável, dialética e paradoxal, indistinta e explosiva das estruturas de criação e das estruturas de destruição no mundo, na cultura humana e a fortiori na religião, que é a dimensão do ser humano que chega mais longe e mais alto, até o Deus acima de Deus, em quem é superada a dialética do fundamento e do abismo. É pela religião que a humanidade recebe as mais altas revelações, mas é também por ela que ela arrisca as maiores perversões. A mesma coisa acontece na devoção a Nossa Senhora Aparecida.

Para mostrar isso, recontamos primeiro a história movimentada da imagem e da devoção, desde a pesca milagrosa até a restauração da imagem quebrada, passando pela construção de várias igrejas, cada uma mais majestosa que a anterior. Uma primeira grande ambiguidade já aparece na natureza dos relatos, nos quais se mesclam lendas populares, história teológica guiada pela Providência e historiografia crítica. As outras ambiguidades se manifestam nas atitudes dos atores envolvidos no culto de Maria: o povo fiel, o clero e as autoridades eclesiásticas, os religiosos redentoristas, o poder político local e nacional, assim como os interesses econômicos em jogo em todos os lugares importantes de peregrinação. O principal eixo da nossa reflexão religa a fé popular - muitas vezes a dos pobres e oprimidos - de um lado, e a fé teologicamente refletida, do outro, inclusive a fé que conduz a reflexão de Tillich.

Embora o nosso teólogo não tenha manifestado, durante a sua carreira, muito interesse ou consideração pela cultura popular, inclusive suas formas artísticas e religiosas, e que seu conhecimento da América latina tenha sido deficiente, o pensamento dele continua pertinente $\mathrm{e}$ atual para a análise da religião no sul do novo continente. É o que foi mostrado por numerosos teólogos e pesquisadores da nossa Pátria Grande. No caso de Nossa Senhora Aparecida, vimos que o maior fervor 
da devoção significa também a maior ameaça de desvio para formas de idolatria, de um lado, e de sufocamento pelo institucional, do outro, até "na melhor das intenções". É quando o santo se aproxima mais da perfeição que ele se expõe à queda mais brutal: Corruptio optimi péssima, já diziam os antigos. O contrário é também verdadeiro: a pessoa mais imersa no mal atrai mais a graça e a misericórdia divina e até pequenos relâmpagos de bondade são computados a seu favor. É a Felix Culpa de Santo Agostinho e o Pecca fortiter de Lutero.

$\mathrm{Na}$ piedade popular, Maria é o último recurso do pecador na beira do abismo da morte física e espiritual. Vejamos, por exemplo, o gesto de Maria na cena do juízo final de Michelangelo, na capela Sixtina: ela puxa o braço do Filho, que está empurrando os injustos para o inferno. Há um magnífico texto teatral no Nordeste, que narra essa história ao modo do povo: o Auto da Compadecida, de Ariano Suassuna. O relato, mesclado de humor e sabedoria popular, encena, num estilo de farsa medieval revisto pelo folclore local, dois jovens vagabundos, Chico e João, que vivem a custo de pessoas ingênuas que se acham expertas: um padeiro e sua esposa, um sacristão, um vigário, um bispo, um fazendeiro e dois cangaceiros. Depois de sua morte violenta, todos se reencontram no Juízo Final, salvo o Chico. O diabo e Jesus apresentam acusações e defesas. João recorre então a Nossa Senhora, para que ela interceda a favor deles, o que ela faz. Todos são mandados para o Purgatório ou para o Paraíso, salvo João, que volta na terra. Os dois companheiros novamente reunidos acabam, apesar de muita hesitação, entregando à Igreja o dinheiro dos seus trambiques e pagam, assim, a promessa do Chico à Virgem Maria, para que João fique são e salvo.

\section{Referências}

ALVAREZ, R. Aparecida: a biografia da santa que perdeu a cabeça, ficou negra, foi roubada, cobiçada pelos políticos e conquistou o Brasil. São Paulo: Globo, 2014.

BRUSTOLONI, J. História de Nossa Senhora da Conceição Aparecida: A imagem, o santuário e as romarias. 10ª . Edição. Aparecida, SP: Santuário, 1998.

GEBARA, I. \& BINGEMER, M. C. Maria, mãe de Deus e mãe dos pobres: um ensaio a partir da mulher e da América Latina. Petrópolis: Vozes, 1987. 
HIGUET, E. Devoção e romaria à Santíssima Trindade - Um olhar simpático na perspectiva de Paul Tillich. Revista Eletrônica Correlatio, vol. 3, $\mathrm{n}^{\circ} 5$, 2004, p. 26-44.

Manual do devoto de Nossa Senhora Aparecida. Aparecida, SP: Santuário, Nova edição, 2009.

RIBEIRO, Z. A. História de Nossa Senhora da Conceição Aparecida e de seus escolhidos. Aparecida, SP: Santuário, 1998.

TILLICH, P. Le christianisme et la rencontre des religions. Genève : Labor et Fides, 2015.

TILliCH, P. The Demonic in Art. In On Art and Architecture. John Dillenberger Ed., New York : Crossroad, 1987, p. 102-118.

TILLICH, P. One Moment of Beauty. In On Art and Architecture. John Dillenberger Ed., New York : Crossroad, 1987, p. 234-235.

TILLICH, P. Substance catholique et principe protestant. Paris-GenèveQuébec : Cerf-Labor et Fides-Presses de l'Université Laval, 1995.

TILLICH, P. Systematic Theology I. London : James Nisbet \& Co Ltd, 1968. TILLICH, P. Systematic Theology III. London : James Nisbet \& Co Ltd, 1968. TILLICH, P. Teologia sistemática. São Leopoldo, RS: Sinodal, 2005. Quinta edição revista.

TILLICH, P. Das Wesen der religiösen Sprache. In Die Frage nach dem Unbedingten, Gesammelte Werke V. Stuttgart : Evangelisches Verlagswerk, 1978, p. 213-222. 